\title{
Tissue retraction in the scleractinian coral Coeloseris mayeri, its effect upon coral pigmentation, and preliminary implications for heat balance
}

\author{
B. E. Brown, M. D. A. Le Tissier, R. P. Dunne \\ Department of Marine Sciences and Coastal Management, University of Newcastle upon Tyne, \\ Newcastle upon Tyne NE1 7RU, United Kingdom
}

\begin{abstract}
Extreme tissue retraction in the agariciid coral Coeloseris mayeri occurs during periods of sub-aerial exposure. The retraction response appears to involve independent movement of oral and aboral tissue layers to such an extent that skeletal septa are uncovered. Tissue retraction results in a significant paling in colony colour which does not involve any reduction in either zooxanthellae abundance or chlorophyll concentration. Adaptive benefits of the response include increased albedo, leading to a reduction in absorbed solar energy of $10 \%$ for wavelengths between 280 and $700 \mathrm{~nm}$, and possible avoidance of photochemical damage or photoinhibition at high solar irradiance. The degree of retraction is governed by environmental conditions, including length of sub-aerial exposure, and intensity of solar irradiance.
\end{abstract}

KEY WORDS: Coral Tissue retraction $\cdot$ Bleaching $\cdot$ Solar radiation $\cdot$ Heat balance

\section{INTRODUCTION}

Expansion/contraction behaviour patterns have been well documented for both corals (Kawaguti 1954, Abel 1963, Porter 1974, Lewis \& Price 1975, Sweeney 1976, Lasker 1979, 1981) and sea anemones (Gladfelter 1975, Sebens \& DeReimer 1977, Shick et al. 1979, Stotz 1979, Shick \& Dykens 1984). Such expansion and contraction rhythms have been attributed to diel cycles of plankton availability, to irradiance (Lewis \& Price 1975, Sebens \& DeRiemer 1977) and, in the special case of intertidal anemones, to behavioural adaptations which minimise the effects of desiccation and photochemical damage (Shick \& Dykens 1984).

While the existence of these behavioural responses has long been recognised, the extent to which a coral polyp may retract is not widely appreciated. The earliest account known to the authors of extreme tissue retraction was that of Moorhouse (1936) in which he describes tissue retraction in sub-aerially exposed Porites species that resulted in the exposure of skeletal spines to air during low spring tides. Moorhouse further describes the subsequent extension of polyp tis- sues over spines on resubmergence of the corals. Although tissue retraction is not mentioned by Fishelson (1973) a similar phenomenon may have been responsible for 'denuded' skeletal spines in mussid and faviid corals, observed on extreme low tides at Eilat, Red Sea. Such tissue responses are not only restricted to intertidal corals since recent work (Coyer et al. 1993) on subtidal Balanophyllia elegans has shown that chronic brushing of corals by macroalgae in water currents causes polyp retraction to such an extent that parts of the coral skeleton become directly exposed to seawater.

In this study extreme tissue retraction is described in the scleractinian coral Coeloseris mayeri which is subaerially exposed on low spring tides at Phuket, Thailand. Tissue retraction in this species results in marked paling of colour which has previously been interpreted as a bleaching response (Ditlev 1978). This paper describes the retraction and recovery of coral tissues over a tidal cycle, the resultant changes in colour of colonies, their relationship to pigment and zooxanthellae concentrations and the possible physiological benefits of such behaviour. 


\section{MATERIALS AND METHODS}

Study location. The project was carried out at Phuket Marine Biological Centre, Thailand, during February 1992 to March 1993. The coral selected for the study, Coeloseris mayeri Vaughan, 1918, is found on sheltered intertidal reefs of the southeast corner of Ko Phuket where it is abundant on the mid-reef flat, its distribution extending to the outer reef edge and upper slope (Ditlev 1978).

Repeated photography of permanent belt transects on the intertidal reefs of southeast Phuket over the period 1979 to 1990 (described in Brown et al. 1990) indicated considerable temporal changes in colouration in a number of coral species; the most marked changes in colour occurring in the agariciid Coeloseris mayeri. In order to follow the changes more carefully a representative colony of $C$. mayeri was photographed at 10 min intervals over part of 5 tidal cycles in 1992, 4 in daylight (2 March, 15:00 to $16: 30 \mathrm{~h} ; 5$ March, 15:30 to $17: 35 \mathrm{~h} ; 10$ March, $06: 00$ to $08: 30 \mathrm{~h} ; 16 \mathrm{March}, 13: 30$ to $17: 30 \mathrm{~h}$ ) and 1 during the night (3 March, 02:00 to 03:30 h). The sequences covered the period from when the colony was submerged, through its emergence and exposure to air, to its subsequent resubmergence by the flooding tide. In order to assist colour comparison, electronic flash and a Kodak colour separation guide (CAT 152 7654) were used.

Additionally, a small portion of the same colony was simultaneously photographed using macrophotography to record any tissue movements. Photographs were taken at $10 \mathrm{~min}$ intervals through the same parts of the tidal cycle as described above.

Chlorophyll concentration and zooxanthellae density. A pair of cores was drilled from 10 submerged and 10 sub-aerially exposed coral colonies, one core from each pair being used for chlorophyll analysis while the other was used for measurement of zooxanthellae density. Cores were extracted from the apex of colonies with an electronic drill fitted with a $25 \mathrm{~mm}$ diameter hole-saw (drill speed $1400 \mathrm{rpm}$ ). Extracted cores were approximately $22 \mathrm{~mm}$ diameter and $20 \mathrm{~mm}$ in length.

Cores extracted for analysis of zooxanthellae densities were fixed in $10 \%$ formalin in seawater while the remaining cores were placed in ice in a sealed, darkened container and returned to the laboratory within 30 min of collection for chlorophyll measurement. Prior to chlorophyll extraction the diameters of cores were measured with vernier callipers. Chlorophyll was extracted according to methods used by Jeffrey \& Haxo (1968). Chlorophyll absorbances were read at 750,665 , 647 and $630 \mathrm{~nm}$ in a Whatman DC500 spectrophotometer and chlorophyll a (chl a) concentrations calculated using the equations described by Jeffrey \& Humphrey (1975). Subtraction of chl a due to endo- lithic algae was carried out as in Jokiel \& Coles (1974).

Zooxanthellae counts were made on fixed cores which were decalcified in a 1:1 mixture of $5 \%$ formic acid and $5 \%$ formalin over a $48 \mathrm{~h}$ period. Prior to decalcification, dimensions of cores were measured with vernier callipers to allow calculation of surface areas. The resultant solutions were centrifuged at $3000 \times g$ for $10 \mathrm{~min}$, the supernatant discarded and the resulting pellet resuspended in $5 \%$ formalin solution which was then homogenised for $12 \mathrm{~min}$ in a Polytron tissue shearer. Numbers of zooxanthellae were counted in subsamples of the resulting solution using an improved Neubauer haemocytometer.

Analysis of tissue/skeleton relationships. Since the removal of a coral colony from the reef could in itself result in tissue retraction, it was important to ensure that any sampling procedure caused minimal alteration to the position of the tissues. In order to do this cores were extracted $48 \mathrm{~h}$ prior to sampling for histological study and the behaviour of tissues compared in both field and laboratory procedures. Twenty coral cores were extracted from 10 colonies in the field (a pair of cores from each colony); pairs of cores from 5 colonies were placed in wire racks adjacent to Coeloseris mayeri colonies on the reef while pairs of cores from the remaining 5 colonies were transported to a running seawater aquarium at the laboratory. After $48 \mathrm{~h}$ cores were sampled before, during and after a natural tidal cycle in the field and at similar intervals for a simulated tide at the laboratory. Between core extraction and fixation all cores were carefully monitored for any signs of damage or stress caused by their collection. Although the edges of the cores exhibited obvious damage from the drilling process, no polyps from the centre of the cores showed any signs of stress; all exhibited 'normal' patterns of polyp expansion and contraction during both day and night, similar to those shown by undisturbed field colonies

Sampled cores were anaesthetised in $1: 1 \quad 0.36 \mathrm{M}$ $\mathrm{MgCl}_{2} \cdot 6 \mathrm{H}_{2} \mathrm{O}$ /seawater solution for $30 \mathrm{~min}$ before fixation in buffered glutaraldehyde (Le Tissier 1988). During anaesthetisation and fixation the position of the tissues within each corallite was carefully noted in all cores; there was no apparent movement of tissues during preparation for histology. After fixation, 1 core from each sampled pair was used in the preparation of polished sections. These cores were washed in $0.1 \mathrm{M}$ sodium cacodylate buffer, dehydrated in a graded series of acetone, and embedded in Emix resin. Longitudinal sections ( $1 \mathrm{~mm}$ thick) of the cores were cut from resin blocks on a Metals Research Microslice 2. The resulting sections were mounted onto glass slides, polished down to $80 \mu \mathrm{m}$ thickness on a Logitech polishing machine, stained with toluidine blue and photographed on a Leitz photomicroscope. 
The remaining core from each sampled pair was decalcified in $2 \%$ ascorbic acid in $0.3 \mathrm{M} \mathrm{NaCl}$, with renewal of demineralising solution every $8 \mathrm{~h}$ until all skeleton had been removed. After dehydration and embedding as above, $1 \mu \mathrm{m}$ sections were cut on an ultramicrotome, mounted onto glass slides and stained with toluidine blue.

Reflectance of corals and solar irradiance. Radiance measurements were taken from a circular area of view of $0.2 \mathrm{~cm}^{2}$ on the surface of a Coeloseris mayeri colony and from an adjacent reflectance standard (Lab. Sphere Inc. NIST traceable), 1 and $60 \mathrm{~min}$ after sub-aerial exposure in bright sunlight using a Macam Photometrics SR 9910 double grating spectroradiometer (bandwidth $2 \mathrm{~nm}$; stray light $<2 \times 10^{-8}$, wavelength accuracy $\pm 0.5 \mathrm{~nm}$ ). The instrument was calibrated before use at $29^{\circ} \mathrm{C}$ against deuterium and tungsten lamps. Scans were made over the range 280 to $700 \mathrm{~nm}$ (step length $1 \mathrm{~nm}$ ) using a reflex viewing telescope with quartz optics oriented perpendicular to the measured surface. Reflectance values were calculated from each pair of radiance scans. Comparative reflectance measurements were also taken from a dry C. mayeri skeleton from which all tissue had been removed after bleaching in sodium hypochlorite solution.

For measurement of solar irradiance on a flat surface, clear sky scans were recorded on 4 March 1993 at Phuket Marine Biological Center using the spectroradiometer fitted with a sealed teflon cosine corrected $2 \pi$ collector oriented parallel to the earth's surface. Sea surface and subsurface irradiance measurements were made with the same instrumentation on 5 March 1993 for clear sky conditions in an $11 \times 5 \times$ $1.5 \mathrm{~m}$ deep tidal pool. Suspended sediment levels in the seawater were measured from four $500 \mathrm{ml}$ water samples which were filtered through preweighed $0.45 \mu \mathrm{m}$ Millepore filters, the filters and retained particulates were dried at $70^{\circ} \mathrm{C}$ and reweighed for estimation of particulate load.

\section{RESULTS}

\section{Colouration changes over the tidal cycle}

Photographs of the mid-reef flat at Ko Phuket at low spring tide, $2 \mathrm{~h}$ after aerial exposure revealed an extensive area of the reef flat occupied by almost white colonies of Coeloseris mayeri (Fig. 1). Selected photographs taken of a single coral colony at the time of sub-aerial exposure during the night $(02: 00$ to $03: 30 \mathrm{~h})$ and during the day $(15: 30$ to $17: 00 \mathrm{~h})$ indicate the change in colour displayed by the coral through part of the tidal cycle (Fig. 2). When submerged at high water the coral appeared green/brown in colour; as the tide receded during bright sunlight, the still-submerged coral began to show patchy paling of colour over its surface; almost immediately on sub-aerial exposure the coral whitened and finally, after 85 min exposure to air, the whole colony was almost white overall, apart from the centre of the calices (Fig. 2c, d). When the same coral was observed at equivalent times in the tidal cycle in the middle of the night (Fig. 2a, b) the colouration of the colony was considerably darker than that observed during bright sunlight.

When the colony was emergent for a very short time during a tidal cycle in the early morning (06:50 to $08: 00 \mathrm{~h}$ ), only that portion of the colony which was sub-aerially exposed actually changed colour from green/brown to almost white (Fig. 4). As the tide flooded back on to the coral, colouration was regained in areas which had formerly been exposed to air; by 08:00 h the coral was fully submerged although a portion of the colony still appeared almost white. Overall green/brown colouration of the whole colony was not achieved until at least $1 \mathrm{~h}$ after resubmergence. Observations in the field indicated that the time for full recovery of colouration was highly variable, depending both on the time of day that low tide occurred and also the period of sub-aerial exposure.

Close-up photography of coral polyps in the field showed that when submerged by water, coral tissues covered the skeleton with the tentacles clearly visible; 5 min after water had withdrawn from the coral surface the tissues appeared to retract although they still covered the skeletal surface (Fig. 3a, b). Approximately $85 \mathrm{~min}$ after initial sub-aerial exposure, the tissues appeared to have completely retracted off the skeleton with the fine granulations on the septa being clearly visible (Fig. 3c). The colony colour changed from green/brown (submergent) to almost white on subaerial exposure. Once the flooding tide covered the coral, the tissues expanded over the skeleton, colouration returned, and tentacles were once more visible (Fig. 3d). Mesenterial filaments were also apparent at the base of the corallites at this stage.

\section{Zooxanthellae density and chlorophyll concentrations}

Comparison of numbers of zooxanthellae per $\mathrm{cm}^{2}$ of almost white sub-aerially exposed colonies and green/brown submerged colonies revealed no significant difference ( $\mathrm{p}>0.05$ ANOVA) between colonies sampled at different states of the tide (Fig. 5). Similarly, comparison of chl a concentration per $\mathrm{cm}^{2}$ and $\mathrm{chl}$ a per zooxanthella showed no significant difference between sub-aerially exposed and submerged colonies (Fig. 5). 


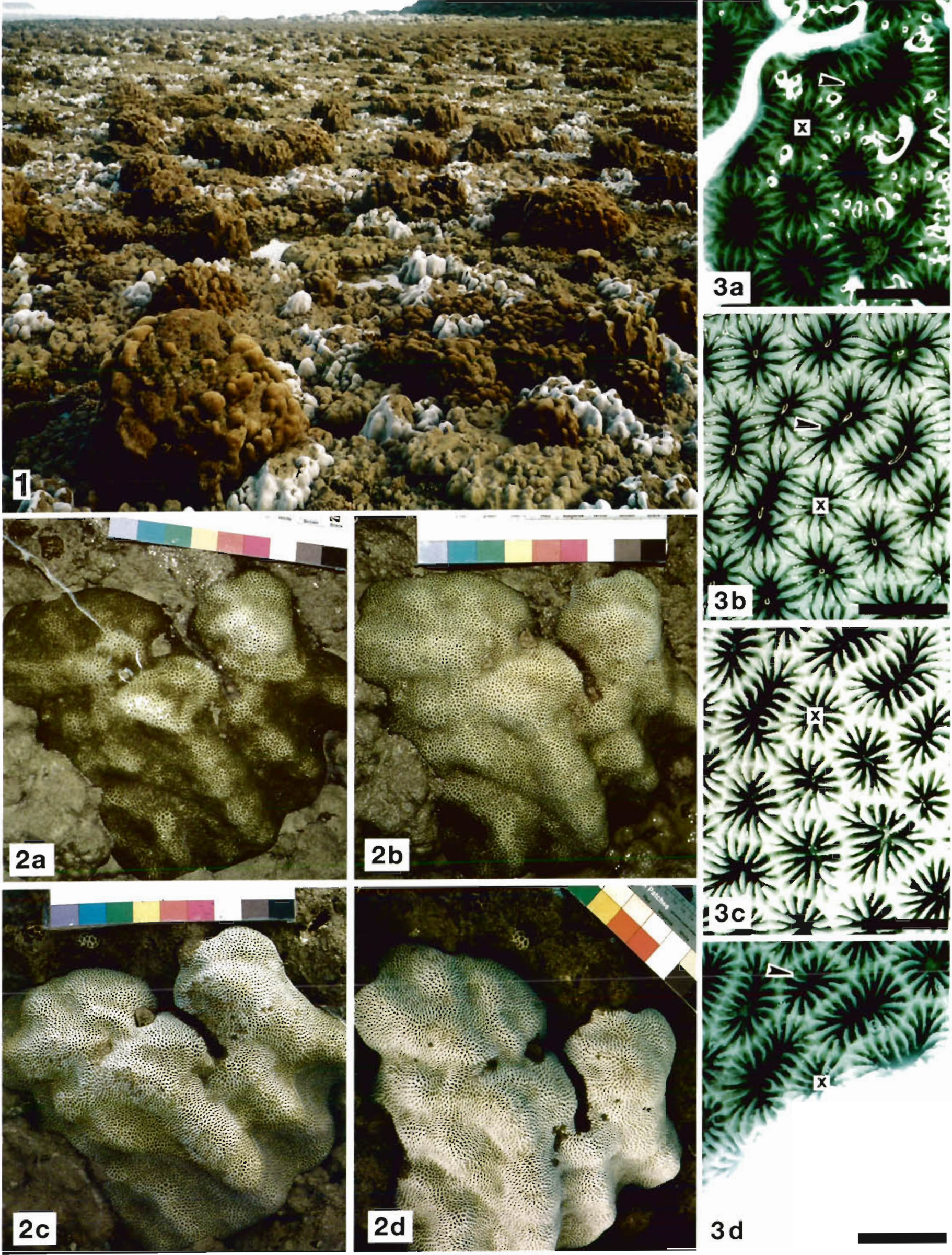


Figs, 1 to 3. Coeloseris mayeri. Fig. 1. View of intertidal reef flat $2 \mathrm{~h}$ after sub-aerial exposure showing extensive areas occupied by whitened C. mayeri. Fig. 2. A selected colony at different times during part of the tidal cycle (March 1992). (a) Receding tide exposes upper part of coral during darkness (02:00 h, $3 \mathrm{Mar}$ ). (b) Coral after being fully exposed to air for 90 min during darkness (03:30 h, 3 Mar). (c) Receding tide exposes upper part of the coral during bright sunlight (15:50 h, $5 \mathrm{Mar}$ ). (d) Coral after being fully exposed to air in bright sunlight for $90 \mathrm{~min}(17: 40 \mathrm{~h}, 5 \mathrm{Mar})$. Fig. 3 . Close-up of $18 \times 15 \mathrm{~mm}$ area of colony shown in Fig. 2 during part of the tidal cycle. ' $X$ ' identifies the same corallite in each photograph. Scale bar $=5 \mathrm{~mm}$. (a) Before exposure to air. Note green colouration and tentacles (arrow) between septa. (b) Five minutes after exposure to air. Note white colouration and tentacles (shown by arrow) retracted into corallites; the corallites have a 'wet' appearance as a result of reflection of flash light from dorsal surfaces of the coral. (c) Approximately 85 min after exposure to air. Note white colouration, absence of tentacles between septa and 'dry' appearance of coral surface. (d) Ten minutes after resubmergence by flooding tide. Note the reappearance of tentacles between septa and presence of mesenterial filaments (arrow)

\section{Interpretation of histological detail}

Both polished sections and sections of decalcified material showed that similar processes occurred in low tide exposures under natural and simulated conditions in the field and laboratory respectively. During subaerial exposure both ectodermal and endodermal tissues were strongly retracted into the corallite with apices of the septa being uncovered by coral tissues (Fig. 6). Coeloseris mayeri has no coenosteum and very steep walled corallites; when the tissue retracts almost all colour is lost from the surface of the coral leaving a very pale appearance to the colony. Once the colony is resubmerged the tissues extend to reoccupy their former position and colour is regained by the coral.
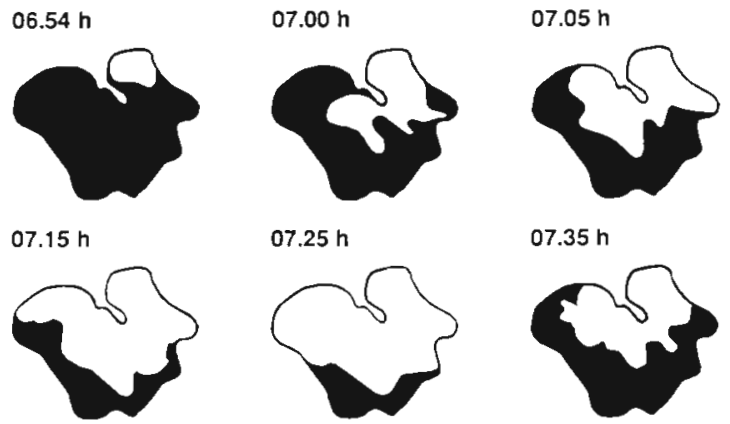

$07.25 \mathrm{~h}$

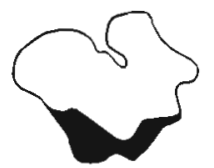

$07.35 \mathrm{~h}$
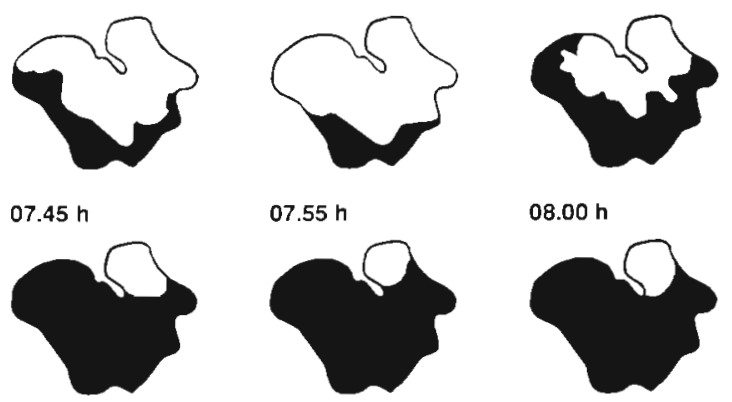

$07.55 \mathrm{~h}$

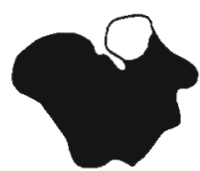

$08.00 \mathrm{~h}$

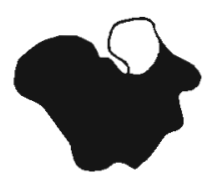

Indicates white retracted portion of colony

Indicates green portion of colony

Fig. 4. Coelosens mayeri. Diagram composed from photographic recordings of a colony over a low tide period, 06:54 to 08:00 h, 10 March 1992, showing changes in colouration during part of the tidal cycle
Histological sections (Fig. 7) reveal a novel mechanism of tissue retraction down skeletal septa with oral tissue layers (i.e. ectoderm, mesoglea and oral endoderm) appearing to retract further down the sides of the septum than aboral tissue layers (aboral endoderm, mesoglea and calicoblastic ectoderm) which remain, during early stages of retraction, in close association with the skeleton. Oral and aboral tissues maintain a region of close contact with each other throughout retraction, thus maintaining the integrity of the gastrovascular space. Such independent movement of tissues appears to result from a separation of oral and aboral layers at the tip of the septa early in the retraction process. Before tissue retraction and during the recovery process oral tissues do not appear to join over the apex of the septum although they abut closely. While zooxanthellae are abundant in oral endoderm covering the septa of non-retracted corals, no zooxanthellae were observed in the aboral endoderm.

\section{Reflectance and irradiance measurements}

Reflectance measurements from Coeloseris mayeri immediately on exposure to air (when the coral was pale but still pigmented) and 1 h later (when the coral appeared maximally retracted and 'white') show an No. of zooxanthellae
$\left(x 10^{7}\right)$ per $\mathrm{cm}^{2}$

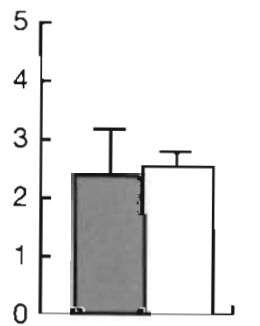

Green submerged colonies
Chlorophyll a conc. per zooxanthella (pg) per $\mathrm{cm}^{2}(\mu \mathrm{g})$
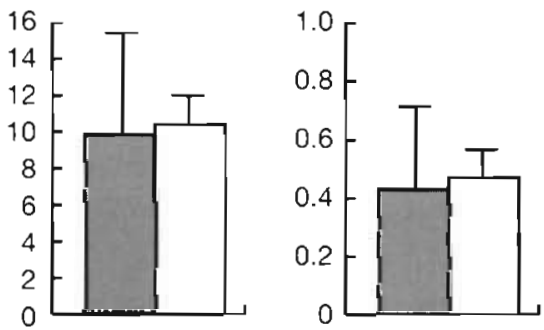

White exposed colonies
Fig. 5. Coeloseris mayeri. Physiological parameters (means + $\mathrm{SD}, \mathrm{N}=10$ ) measured in green submerged colonies and white aerially exposed colonies 


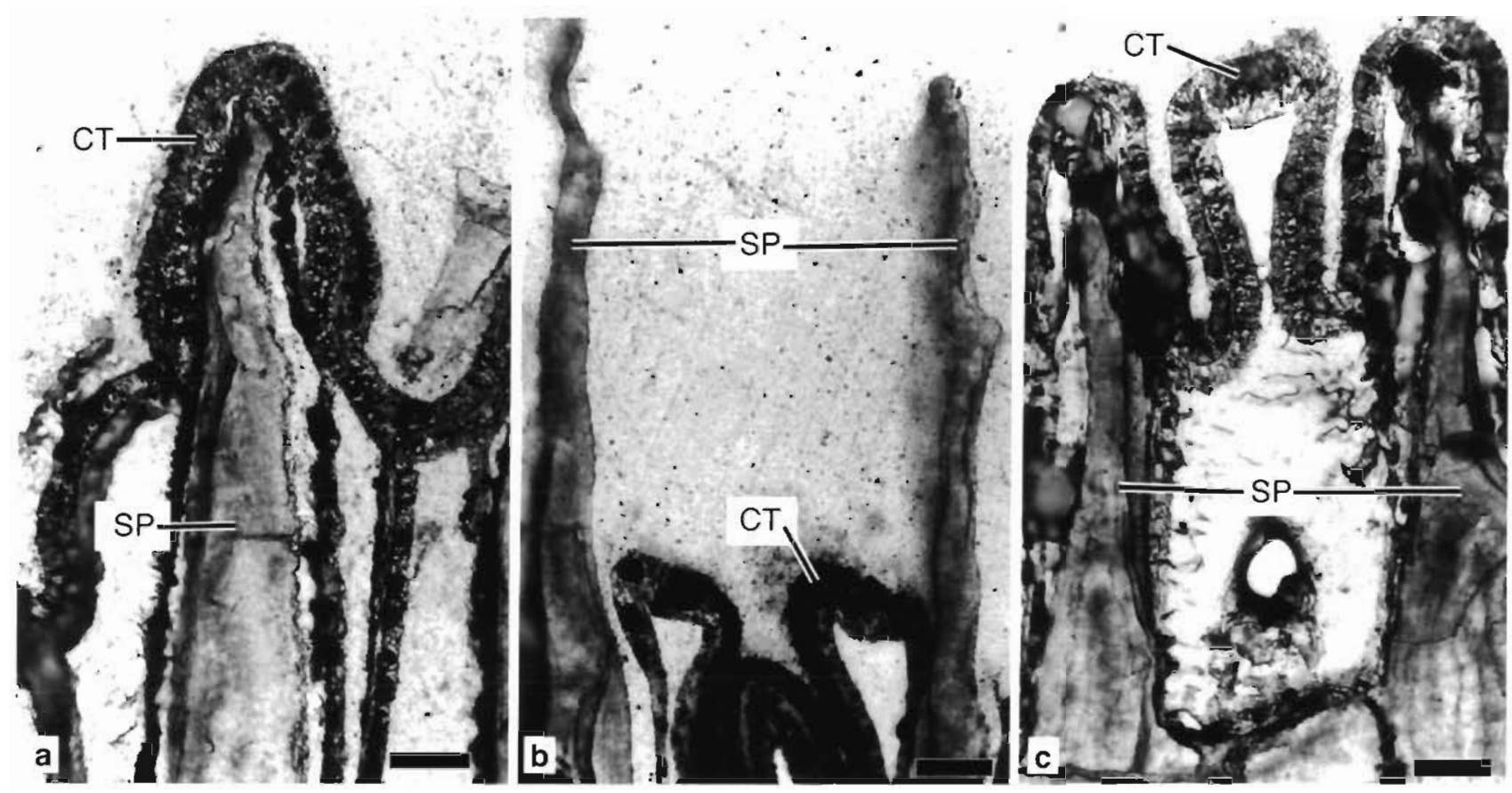

Fig. 6. Coeloseris mayeri. Polished thin $(80 \mu \mathrm{m})$ sections of skeleton and tissues covering the corallite wall; scale bar $=0.1 \mathrm{~mm}$. (a) Before sub-aerial exposure. Note tissues (CT) covering exert septa (SP). (b) Approximately 100 min after sub-aerial exposure. Note the absence of tissues covering septa and the presence of strongly retracted tissues (CT) towards the base of the septa. (c) Approximately 60 min after resubmergence by flooding tide. Note coral tissues covering all margins of the septa

increase in albedo as the pigmentation decreased due to tissue retraction (Fig. 8). Reflectances within specific wavebands indicate that both the 'pale' (partially retracted) and white (maximally retracted) corals absorbed all short wavelength ultraviolet radiation (UVR) (280 to $320 \mathrm{~nm}$ ) compared with an average $5 \%$ reflectance from the chemically bleached skeleton (reflectance standard scans showed reflected UVR to be present down to $313 \mathrm{~nm}$ at the time the maximally retracted coral was scanned and at $303 \mathrm{~nm}$ during the scan of the partially retracted coral). For UVR between 320 and $400 \mathrm{~nm}$ the maximally retracted coral and the chemically bleached skeleton showed a very similar reflectance response (average $17 \%$ and $18 \%$ respectively) whilst the partially retracted coral reflected only $5 \%$ of the irradiance. In the photosynthetically active radiation (PAR) or visible range (400 to $700 \mathrm{~nm}$ ) the chemically bleached skeleton reflected an average $42 \%$ of the irradiance, the maximally retracted coral $22 \%$ and the partially retracted coral $12 \%$

The clear sky irradiance scan for the beginning of a typical afternoon sub-aerial exposure period during March $\left(14: 30 \mathrm{~h}\right.$, sun altitude $\left.59^{\circ}\right)$ gave a value of total irradiance of $460 \mathrm{~W} \mathrm{~m}^{-2}$ across the waveband 280 to $700 \mathrm{~nm}$. In order to calculate the potential reduction in radiant energy absorption as a result of the albedo, the reflectance at each wavelength was multiplied by the corresponding solar irradiance and summed across the waveband (solar energy is not uniformly distributed across the spectrum). In the partially retracted state Coeloseris mayeri reflects $53 \mathrm{~W} \mathrm{~m}^{-2}(11.5 \%)$ compared with $98 \mathrm{~W} \mathrm{~m}^{-2}(21.3 \%)$ in the fully retracted state. On the assumption that a massive coral colony only absorbs or reflects radiant solar energy (no transmittance) the increased albedo will thus result in a reduction in absorbed energy of $9.8 \%$.

In addition to a reduced radiant energy absorption, tissue retraction during sub-aerial emergence also offers the potential for shading of selected structures from high solar irradiance. Our measurements of solar irradiance for clear sky conditions on 5 March 1993 just above the sea surface $\left(13: 18 \mathrm{~h}\right.$, sun altitude $\left.73^{\circ}\right)$ gave values of $2.68 \mathrm{~W} \mathrm{~m}^{-2}$ for the waveband 280 to $320 \mathrm{~nm}$ and $497 \mathrm{~W} \mathrm{~m}^{-2}$ for 400 to $700 \mathrm{~nm}$. When the sensor was submerged $(-2 \mathrm{~cm})$ below a calm water surface $\left(13: 28 \mathrm{~h}\right.$, sun altitude $\left.71^{\circ}\right)$ the comparative values were $1.45 \mathrm{~W} \mathrm{~m}^{-2}$ and $324 \mathrm{~W} \mathrm{~m}^{-2}$ respectively. Seawater clarity in the tidal pool was typical for the sediment laden waters which are a feature of the intertidal reefs at Phuket [mean suspended sediment 2.85 ( \pm 0.03 SD) $x$ $10^{-2} \mathrm{~g} \mathrm{l}^{-1}, \mathrm{n}=4 \mathrm{l}$. These irradiance values illustrate the considerable increase $(85 \%$ between 280 and $320 \mathrm{~nm}$; $53 \%$ between 400 and $700 \mathrm{~nm}$ ) which occurs during the transition from very shallow submergence to subaerial exposure for the intertidal reefs at this location during the early afternoon spring tides. 

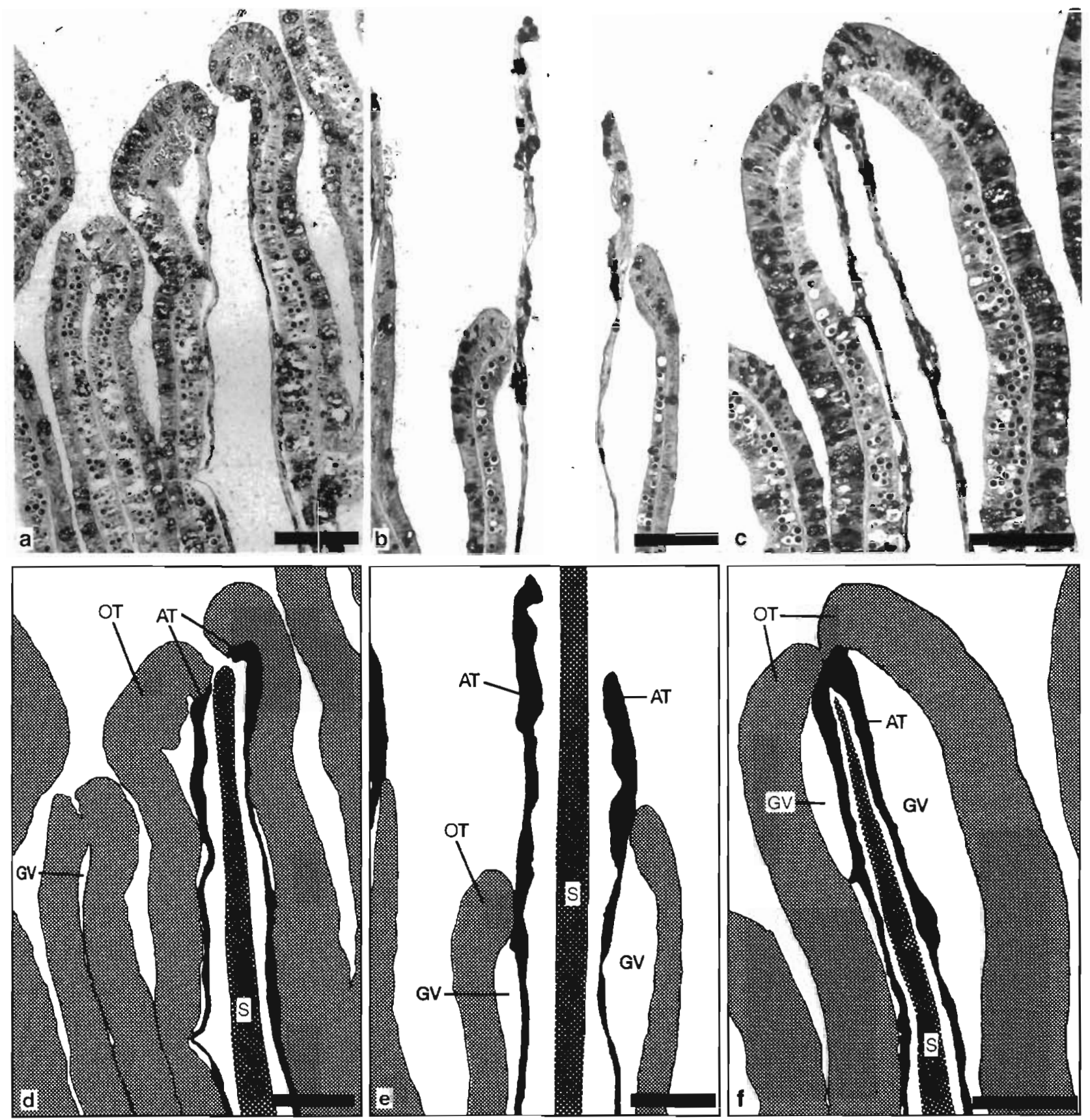

Fig. 7 Coeloseris mayeri. Photomicrographs of longitudinal sections through the decalcified tissues overlying septal apices (a) before exposure to air; (b) approximately $100 \mathrm{~min}$ after sub-aerial exposure; and (c) 10 min after resubmergence by flooding tide. (d), (e) and (f) represent the position of oral tissues (OT), aboral tissues (AT) and gastrovascular space (GV) in photomicrographs (a), (b) and (c) respectively. The position that septa (S) would have occupied is also shown. Note that the septum in (b) [shown in $(e)]$ would extend beyond the top of the photomicrograph. Scale bars $=100 \mu \mathrm{m}$

\section{DISCUSSION}

Polyp retraction as a stress response has been extensively documented (Horridge 1957, Hubbard 1974, Jaap \& Wheaton 1975, Bak \& Elgershuizen 1976, Thompson et al. 1980, Neff \& Anderson 1981). In the coral Coeloseris mayeri retraction behaviour in response to bright sunlight and sub-aerial exposure is particularly marked, producing not only withdrawal of tentacles, as observed in other species, but the complete retraction of tissue off parts of the skeleton. Such a dramatic behaviour is not restricted to $C$. mayeri 


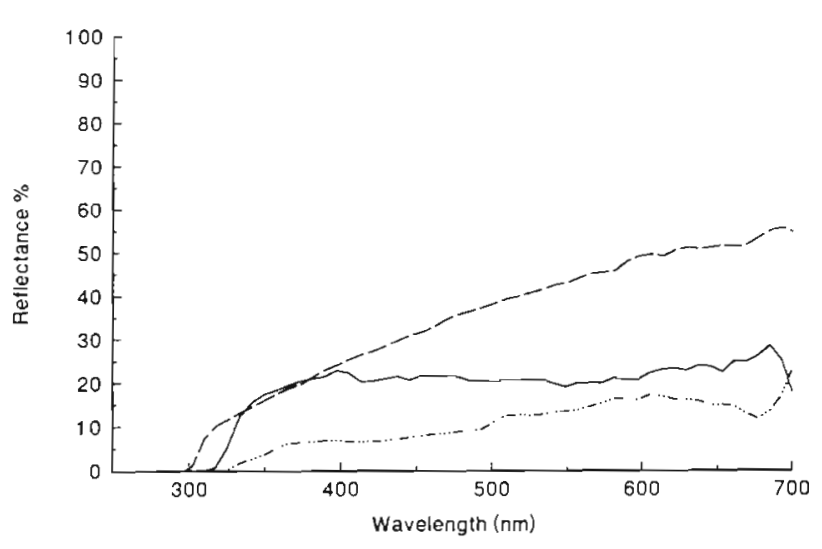

Fig. 8. Coeloseris mayeri. Reflectance between 280 and $700 \mathrm{~nm}$. (--) Chemically bleached skeleton; (- - maximally retracted state; $(-\cdots-)$ partially retracted state

alone. Extreme retraction of tissues has also been observed in Porites lutea, Goniastrea aspera and Goniopora stokesii under experimental conditions where the corals were exposed to high concentrations of iron in seawater and where tissue retracted of skeletal spines (Brown et al. 1991). Tissue retraction, in response to stress, was also proposed as a mechanism by which at least 8 species of intertidal corals, namely Platygyra sinensis, Platygyra daedalea, Goniastrea aspera, Goniastrea pectinata, Favia pentagona, Porites lutea and Fungia fungites, incorporated iron into their skeletons during periods of exposure to ore washings (Brown et al. 1991). Results from the present study pose the possibility that the deposition of iron may have resulted from a regular tissue retraction behaviour on low spring tides in these species which was coincident with discharge of ore washings rather than from exposure to high iron concentrations alone.

The degree of retraction noted in the present study appears to vary according to environmental conditions. For example corals sub-aerially exposed at night appeared less retracted than those exposed during the day; and maximum reduction in colour was observed during extended periods of sub-aerial exposure in bright sunlight. A number of factors may influence the degree of retraction including irradiance (both UVR and PAR), substrate and air temperatures, and humidity. In earlier work with symbiotic sea anemones, Pearse (1974) showed that anemones expanded in moderate light and contracted in intense light with striking uniformity. In the retracted state a large number of the polyp's zooxanthellae will be shaded (Lasker 1979) thus affording some protection from harmful irradiance. Our measurements of solar irradiance above sea surface compared to just below $(-2 \mathrm{~cm})$ show decreases of the order of $46 \%$ (UVR 280 to $320 \mathrm{~nm}$ ) and $34 \%$ (PAR 400 to $700 \mathrm{~nm}$ ) as a result of submergence. These values are comparable to that recorded by Weinberg (1976) for his 'apparent albedo' of the sea surface of a $35 \%$ reduction in irradiance $(420$ to $540 \mathrm{~nm}$ ) for a solar altitude of $67^{\circ}$ under a bright sky. The type of retraction shown by Coeloseris mayerii in its transition from shallow submergence to sub-aerial exposure could be a protective response against potentially damaging photochemical or radiant energy effects of this marked change in irradiance regime.

In terms of possible protection against photochemical damage, at shorter wavelength UVR (280 to $320 \mathrm{~nm}$ ), where the quantum energy targets proteins, DNA and RNA (Coohill 1991), there are no obvious benefits from retraction behaviour, since total absorption occurs whatever the behavioural state of the tissues. It may be however that retraction permits more susceptible tissues, containing the zooxanthellae, to be positioned deeper into the coral calices below a layer of mucus which has been shown in other coral species to contain protective S320-UVR-absorbing compounds (Drollet et al. 1993). Similarly at longer wavelengths of UVR ( 320 to $400 \mathrm{~nm}$ ) where there is no difference in reflectance between the partially and maximally retracted state, there is also no obvious gain. In contrast, between 400 to $700 \mathrm{~nm}$ (PAR) where a major target for photochemical damage or photoinhibition would involve the zooxanthellae photosystems, the $10 \%$ gain in reflectivity gives added protection to that which might arise from the increased shielding of zooxanthellae by the coral skeleton, mucus and tissue layers.

Retraction may also offer some limited benefits in the thermal balance of an intertidal coral. In the case of radiant energy absorption, the overall saving in a retracted 'white' coral compared with a partially retracted 'pale' coral is in the order of $10 \%$ across the waveband 280 to $700 \mathrm{~nm}$. This compares with studies in other intertidal invertebrates, in particular the blanching (whitening) response of the carapace of fiddler crabs Uca rapax and $U$. pugilator where an interaction between solar irradiance and blanching was found (Smith \& Miller 1973). For U. pugilator mean reflectance over the waveband 400 to $1100 \mathrm{~nm}$ increased from 25 to $50 \%$ as a result of blanching. Earlier work by Wilkens \& Fingerman (1965) on $U$. pugilator showed that blanching resulted in a reduction in body temperature of about $2^{\circ} \mathrm{C}$ under bright sunlight for an observed increase in reflectance measured in the waveband 400 to $700 \mathrm{~nm}$ from about 2.5 to $7 \%$. Although Wilkens \& Fingerman (1965) recorded much lower levels of reflectance than Smith \& Miller (1973), the results are not wholly inconsistent since the reflectance values recorded in the latter work were dominated by high values recorded in the infrared (700 to $1000 \mathrm{~nm}$ ). 
Despite evidence for a reduction in absorbed radiant energy which increased albedo may confer, such benefits need to be viewed in the context of potential cooling due to evaporation of water from the coral surface and/or polyp. The increased reflectance of a fully retracted compared with a partially retracted coral reduces absorption by a typical $45 \mathrm{~W} \mathrm{~m}^{-2}$ or $2.7 \times 10^{3} \mathrm{~J}$ $\mathrm{m}^{-2} \mathrm{~min}^{-1}$, compared with the potential heat loss by evaporation of $1 \mathrm{~g}(=1 \mathrm{ml})$ of water of about $2.34 \times$ $10^{3} \mathrm{~J}$. Although no information is available for intertidal corals, evaporation has long been recognised as the most important source of heat loss in intertidal organisms (Newell 1979).

There is evidence that extreme retraction responses are widespread among a number of coral genera on the reef flat and, furthermore, that they are not restricted only to intertidal corals. Brushing by overtopping macroalgae caused extreme tissue retraction in subtidal Balanophyllia elegans (Coyer et al. 1993) while similar behaviour by cirri of barnacles resident in Goniastrea retiformis causes retraction in surrounding coral polyps (pers. obs.). In the present study submerged shallow water ( $<1 \mathrm{~m}$ water depth) colonies of Coeloseris mayeri also showed tissue retraction in bright sunlight which resulted in patchy paling of colour over the colony; such behaviour has also been observed on the apical surfaces of Leptoria phrygia, Goniastrea retiformis and Galaxea fascilaris in shallow, well-illuminated waters of the Maldives (unpubl. obs.). A possible factor in retraction behaviour in these latter examples is likely to be solar irradiation, with similar contraction in submerged symbiotic anemones occurring in response to high natural levels of ultraviolet radiation and hyperoxia (Dykens \& Shick 1984, Shick \& Dykens 1984).

Colouration of corals in the field is extremely difficult to quantify as a number of bleaching investigations have already highlighted (Gates 1990, Hayes \& Bush 1990, Lang et al. 1992). Tissue movements during bright sunlight and aerial exposure in Coeloseris mayeri result in visible paling of the colour of colonies which does not involve loss of either zooxanthellae or the photosynthetic pigments, as noted in bleaching responses. In addition recent unpublished results indicate an almost 2 -fold increase in chlorophyll concentrations in C. mayeri on a seasonal basis suggesting that seasonal photoacclimatisation as noted in anemones (Dykens \& Shick 1984) and more recently in corals (Al-Sofyani \& Davies in press) may also affect coral colouration throughout the year. Studies such as the present one indicate the need for better understanding of behavioural responses of both intertidal and shallow subtidal coral species if variations in colouration are to be correctly interpreted.
The extent, nature and significance of extreme tissue retraction in corals is worthy of further study for the phenomenon has the potential not only to affect apparent pigmentation of corals, but also the incorporation of chemicals into coral skeletons (Budd et al. 1993), local skeletal extension rates (Barnes \& Lough 1993) and the scope for invasion of the skeleton by algae and other endolithic organisms (Moorhouse 1936).

Acknowledgements. We thank the Director and staff of the Phuket Marine Biological Centre for their continued support, particularly Dr Hansa Chansang and $\mathrm{Mr}$ Niphon Phongsuwan. We are also grateful to the Natural Environment Research Council who funded part of this project through NERC grant no. GR/453, to the Leverhulme Trust for support of M.L.T and to the Natural Resources and Environment Department of the Overseas Development Administration for support in environmental monitoring.

\section{LITERATURE CITED}

Abel, E. (1963). Rhythmik bei Anthozoen. Neptun 12: $331-333$

Al-Sofyani, A., Davies, P. S. (in press). Seasonal variation in production and respiration of Red Sea corals. Proc. 7 th int. coral Reef Symp.

Bak, R. P. M., Elgershuizen, J. H. B.W. (1976). Patterns of oilsediment rejection in corals. Mar. Biol. 54: 105-113

Barnes, D. J., Lough, J. M. (1993). On the nature and causes of density banding in massive corals. J exp. mar. Biol. Ecol. 167: 91-108

Brown, B. E., Le Tissier, M. D. A., Scoffin, T. P., Tudhope, A. W. (1990). Evaluation of the environmental impact of dredging on intertidal reefs at Ko Phuket, Thailand, using ecological and physiological parameters. Mar. Ecol. Prog. Ser. 65: 273-281

Brown, B. E., Tudhope, A. W., Le Tissier, M. D. A., Scoffin, T P. (1991). A novel mechanism for iron incorporation into coral skeletons. Coral Reefs 10: 211-215

Budd, A. F., Mann, K. O., Guzman, H. M. (1993). Environmental interpretation using insoluble residues within reef coral skeletons: problems, pitfalls and preliminary results. Coral Reefs 12: 31-42

Coohill, T. P. (1991). Photobiology school. Action spectra again? Photochem. Photobiol. 54: 859-870

Coyer, J. A., Ambrose, J. M., Engle, J. M., Carroll, J. C. (1993). Interactions between corals and algae on a temperate zone rocky reef: mediated by urchins. J. exp. mar. Biol. Ecol. 167: 21-37

Ditlev, H. (1978). Zonation of corals (Scleractinia: Coelenterata) on intertidal reef flats at Ko Phuket, Eastern Indian Ocean. Mar. Biol. 47: 29-39

Drollet, J. H., Glaziou, P., Martin, P. M. V. (1993). A study of mucus from the solitary coral Fungia fungites (Scleractinia: Fungiidae) in relation to photobiological UV adaptation. Mar. Biol. 115: 263-266

Dykens, J. A., Shick, J. M. (1984). Photobiology of the symbiotic sea anemone Anthopleura elegantissima: defences against photodynamic effects and seasonal photoacclimation. Bial. Bull. 167: 683-697

Fishelson, L. (1973). Ecological and biological phenomena influencing coral species composition on the reef tables at Eilat (Gulf of Aqaba, Red Sea). Mar. Biol. 19: 183-196 
Gates, R. D. (1990). Seawater temperature and sublethal coral bleaching in Jamaica. Coral Reefs 8: 193-197

Gladfelter, W. B. (1975). Sea anemone with zooxanthellae: simultaneous contraction and expansion in response to changing light intensity. Science 189: 570-571

Hayes, R. L., Bush, P. G. (1990). Microscopic observations of recovery in the reef-building scleractinian coral Montastrea annularis, after bleaching on a Cayman reef. Coral Reefs 8: 203-209

Horridge, G. A. (1957). The co-ordination of the protective retraction of coral polyps. Phil. Trans. R. Soc. Lond. Ser. B. 240: $495-528$

Hubbard, J. A. E. B. (1974). Scleractinian coral behaviour in calibrated current experiment: an index to their distribution patterns. Proc. 2nd int. Coral Reef Symp. 2: 107-126

Jaap, W. C., Wheaton, J. (1975). Observations on Florida Reef corals treated with fish collecting chemicals. Fla mar. Res. Publ. 10: 1-17

Jeffrey, S. W., Haxo, F. T (1968). Photosynthetic pigments of symbiotic dinoflagellates (zooxanthellae) from corals and clams. Biol. Bull. 135: 149-165

Jeffrey, S. W., Humphrey, G. F. (1975). New spectroscopic equations for determining chlorophylls $a_{1} b_{1} c_{1}$ and $c_{2}$ in higher plants, algae and natural phytoplankton. Biochem. Physiol. Pflanz. 167: 191-194

Jokiel, P. L., Coles, S. L. (1974). Effects of heated effluent on hermatypic corals at Kahe Point, Oahu. Pacif. Sci. 28: 1-18

Kawaguti, S. (1954). Effects of light and ammonium on the expansion of polyps in the reef corals. Biol. J. Okayama Univ. 2: 45-50

Lang, J. D., Lasker, H. R., Gladfelter, E. H., Hallock, P., Jaap, W. C., Losada, F. Y., Muller, R. G. (1992). Spatial and temporal variability during periods of 'recovery' after mass bleaching on Western Atlantic coral reefs. Am. Zool. 32: 696-706.

Lasker, H. R. (1979). Light dependent activity patterns among reef corals: Montastrea annularis. Biol. Bull. 156: 196-211

Lasker, H. R. (1981). Phenotypic variation in the coral Montastrea cavemosa and its effects on colony energetics. Biol. Bull. 160: 292-302

Le Tissier, M. D. A. (1988). Diurnal patterns of skeleton formation in Pocillopora damicornis (Linnaeus). Coral Reefs 7: $81-88$

Lewis, J. B., Price, W. S. (1975). Feeding strategies of Atlantic reef corals. J. Zool. Lond. 176: 527-544

This article was submitted to the editor
Moorhouse, F. W. (1936). The cyclone of 1934 and its effect on low isles, with special observations on Porites. Rep. Gt Barrier Reef Comm. 4: 37-44

Neff, J. M. Anderson, J. W. (1981). Response of marine animals to petroleum and specific petroleum hydrocarbons. Applied Science Publ., London, p. 177-221

Newell, R. C. (1979). Biology of intertidal animals. Marine Ecological Surveys Ltd, Faversham

Pearse, V. B. (1974). Modification of sea anemone behaviour by symbiotic zooxanthellae: expansion and contraction. Biol. Bull. 147: 641-651

Porter, J. W. (1974). Zooplankton feeding by the Caribbean reef-building coral Montastrea cavernosa. Proc. 2nd int. coral Reef Symp. 1: 111-125

Sebens, K. P., DeRiemer, K. (1977). Diel cycles of expansion and contraction in coral reef anthozoans. Mar. Biol. 43 $247-256$

Shick, J. M., Brown, W. I., Dolliver, E. G., Kayar, S. R. (1979) Oxygen uptake in sea anemones: effects of expansion, contraction and exposure to air and the limitations of diffusion. Physiol. Zool. 52: 50-62

Shick, J. M., Dykens, J. A. (1984). Photobiology of the symbiotic sea anemone Anthopleura elegantissima: photosynthesis, respiration and behaviour under intertidal conditions. Biol. Bull. 166: 608-619

Smith, W. K., Miller, P. C. (1973). The thermal ecology of two south Florida fiddler crabs: Uca rapax Smith and U. pugilator Bosc. Physiol. Zool. 46: 186-207

Stotz, W. B. (1979). Functional morphology and zonation of three species of sea anemones from rocky shores in southern Chile. Mar. Biol. 50: 181-188

Sweeney, B. M. (1976). Circadian thythms in corals, particularly Fungiidae. Biol. Bull. 151: 236-246

Thompson, J. H., Shinn, E. A., Bright, T J. (1980). Effects of drilling mud on seven species of reef-building corals as measured in the field and laboratory. In: Geyer, R. A. (ed.) Marine environmental pollution: hydrocarbons. Elsevier Oceanography Series 27, Elsevier, p. 433-453

Weinberg, S. (1976). Submarine daylight and ecology. Mar. Biol. 37: 291-304

Wilkens, J. L., Fingerman, M. (1965). Heat tolerance and temperature relationships of the fiddler crab, Uca pugilator, with reference to body coloration. Biol. Bull. 128(1): $133-141$

Manuscript first received: June 10,1993

Revised version accepted: November 25, 1993 